\title{
CHEMICAL COMPOSITION, PHENOLIC, TANNIN AND ANTIOXIDANT ACTIVITY IN WATER AND METHANOL EXTRACT FROM MARINE MICROALGAE Oscillatoria $s p$.
}

\author{
Nurhasanah $^{1}$, Ratnawati Lilasari Djanis ${ }^{2}$ and Askal Maimulyanti ${ }^{3, 凶}$ \\ ${ }^{1}$ Department of Quality Assurance of Food Industry, Politeknik AKA Bogor, Indonesia \\ ${ }^{2}$ Department of Waste Treatment of Industry, Politeknik AKA Bogor, Indonesia \\ ${ }^{3}$ Department of Analytical Chemistry, Politeknik AKA Bogor, Indonesia \\ ${ }^{\otimes}$ Corresponding Author: askal_m@yahoo.com
}

\begin{abstract}
The Oscillatoria sp microalgae have the potential for functional food because it has a high antioxidant activity, phenolic content, and tannin content. This experiment used the extract of microalgae in water and methanol solvent. The structure of chemical composition using FTIR analysis resulted in the functional group of $\mathrm{O}-\mathrm{H}, \mathrm{C}=\mathrm{C}, \mathrm{C}-\mathrm{H}, \mathrm{C}-\mathrm{O}-$ $\mathrm{P}, \mathrm{O}-\mathrm{CH}_{3},-\mathrm{N}=\mathrm{O}, \mathrm{S}=\mathrm{O}, \mathrm{C}-\mathrm{N}$, and $\mathrm{C}-\mathrm{O}-\mathrm{O}-\mathrm{C}$. The peak amount in water extract is more than methanol extract. The water extract analysis gave the antioxidant activity with $\mathrm{IC}_{50}$ of $0,16 \mu \mathrm{g} / \mathrm{mL}$, phenolic content of $232 \mathrm{mg} / \mathrm{g}$, and tannin content of $479.23 \mathrm{mg} / \mathrm{L}$. The methanol extract analysis gave the antioxidant activity with $\mathrm{IC}_{50} \mathrm{of} 0.85 \mu \mathrm{g} / \mathrm{mL}$, phenolic content of $201 \mathrm{mg} / \mathrm{g}$ and tannin content of $319.45 \mathrm{mg} / \mathrm{L}$. The water extract has a high potential for functional food than methanol extract because in water extract antioxidant activity, phenolic content, and tannin were more than methanol extract.
\end{abstract}

Keywords: Oscillatoria sp, Antioxidant, Chemical Composition.

RASĀYAN J. Chem., Vol. 14, No.2, 2021

\section{INTRODUCTION}

Blue-green algae cyanobacteria is a type of algae that can live in seawater and freshwater. One of the cyanobacteria microalgae is Oscillatoria $s p$. It has the potential to produce beneficial ingredients such as polysaccharides, hormones, vitamins, minerals, protein, and bioactive compounds. ${ }^{1,2}$ This group of algae has potential as an antioxidant ${ }^{3}$ and anti-inflammatory ${ }^{4}$ and it can be used for nutraceutical and functional food. ${ }^{5}$

Most of the natural antioxidants are derived from terrestrial plants but they can also find in unicellular microalgae as an alternative source of natural antioxidants. Microalgae is a novel source of natural antioxidants and used as additives in the food industry. ${ }^{6}$ The microalgae can prevent the accumulation of free radicals. ${ }^{7}$ The important class of antioxidants in microalgae is phenolic compounds. The antioxidant of microalgae correspondent to phenolic compounds. The fraction that has rich in phenolic compounds also had a high antioxidant capacity. Phenolic compounds are important antioxidants. They can donate an electron or a hydrogen atom to form the stable radical. ${ }^{8}$

Many researches has been reported on the antioxidant activity in microalgae ${ }^{9}$ such as Spirulina plantesi $i^{10}$, Haematococcus pluvialis ${ }^{11}$, Synechococcus ${ }^{12}$, Brotyococcus braunii ${ }^{13}$, and Phorpridium sp. ${ }^{14}$ The group of cyanobacteria and potential for anti-cancer, anti-bacteria, and antioxidant. ${ }^{15-17}$ The potential of Oscillatoria $s p$ as an antioxidant is limited to reported by the researcher. The chemical composition included functional group influences of the characteristic of microalgae as bioactive which act as antioxidants and other functions. It is necessary to the identification of the chemical composition of microalgae.

In this study, we investigated the chemical composition and contributed to phenolic substance to antioxidant activity from extract Oscillatoria $s p$ in water and methanol solvent. The method to measure antioxidant activity was 1,1-diphenyl-2-picryl-hydrazyl free radical (DPPH) scavenging and the phenolic content was estimated by the folin-ciocalteu procedure. The potential for functional food by analyzed of tannin in this extract. 
RASĀYAN J. Chem.

Vol. 14 | No. 2 |1159-1164| April - June | 2021

\section{Extraction}

\section{EXPERIMENTAL}

Oscillatoria sp extraction was done using water and methanol extract. 2 grams of samples was dissolved in $250 \mathrm{~mL}$ water and $250 \mathrm{~mL}$ methanol. The sample was stirred at $150 \mathrm{rpm}$ for 24 hours. The extract was filtered and residues were extracted until a colorless filtrate. The solvent was evaporated and used for analysis.

\section{Antioxidant Activity by DPPH Method}

Antioxidant activity was measured by the DPPH method. It is calculated as $\mathrm{IC}_{50} .250 \mathrm{mg}$ extract was dissolved in $50 \mathrm{~mL}$ of methanol. The volume of solution $0.1,0.25,0.5,1.0,2.0 \mathrm{ml}$ added of $5 \mathrm{~mL}$ methanol. A blank solution was made from $11 \mathrm{~mL}$ of DPPH solution into a test tube and added $5 \mathrm{~mL}$ of methanol. All samples and blanks were stored in $37^{\circ} \mathrm{C}$ for 30 minutes and it was measured at $517 \mathrm{~nm}$ wavelength using spectrophotometer UV-Vis. The \% inhibition was calculated and a linear equation was determined between the concentration of sample and \% inhibition. ${ }^{18}$

\section{Determination of Phenolic Content}

Analysis of phenol content measured by the spectrophotometric method using Folin-Ciocalteu reagents. The concentration of the extract was $10 \mathrm{ppm}$ and a volume of $0.1 \mathrm{~mL}$ was added folin-ciocalteu reagent in the ratio of $1: 2$ (reagent: aqua distillation) added $1 \mathrm{~mL}$ of $\mathrm{Na}_{2} \mathrm{CO}_{3} 7 \%$ and incubated for 30 minutes. Absorbance was measured at a wavelength of $750 \mathrm{~nm}$. The standard solution used gallic acid with concentrations of $0,20,40,60$, and $80 \mathrm{mg} / \mathrm{L} .{ }^{19}$

\section{Determination of Tannin Content}

$0.05 \mathrm{~g}$ of extract was added to $50 \mathrm{~mL}$ of hot water and incubated for 20 minutes. The solution was filtered and $2 \mathrm{~mL}$ of supernatant added $150 \mathrm{~mL}$ aqua distillation, $5 \mathrm{~mL}$ indigo carmine and titration with $\mathrm{KMnO}_{4}$ $0.1 \mathrm{~N}$ with the color changed from blue to yellow. $10 \mathrm{~mL}$ filtrate added $10 \mathrm{~mL} \mathrm{NaCl}$-acid, $5 \mathrm{~mL}$ gelatin and $1 \mathrm{~g}$ kaolin $(a \mathrm{~mL})$. The solution was filtered, and $5 \mathrm{~mL}$ of filtrate added $150 \mathrm{~mL}$ aqua distillation and $5 \mathrm{~mL}$ indigo carmine and titration with $\mathrm{KMnO}_{4} 0,1 \mathrm{~N}(b \mathrm{~mL}){ }^{1}$

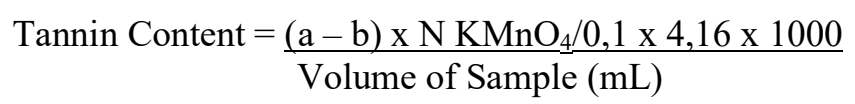

Where,

$\mathrm{a}=$ Sample volume for titration $(\mathrm{mL})$

$\mathrm{b}=$ Blank volume for titration $(\mathrm{mL})$

\section{Chemical Composition}

\section{RESULTS AND DISCUSSION}

The chemical composition identified using FTIR analysis for detected of functional group in extracts of Oscillatoria $s p$.

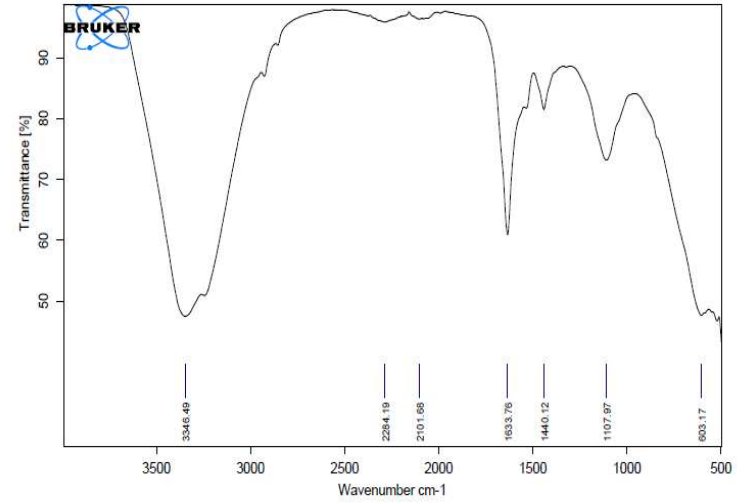

Fig.-1: Spectrum of Infrared from Oscillatoria $S p$ (a) Methanol Extract, (b) Water Extract

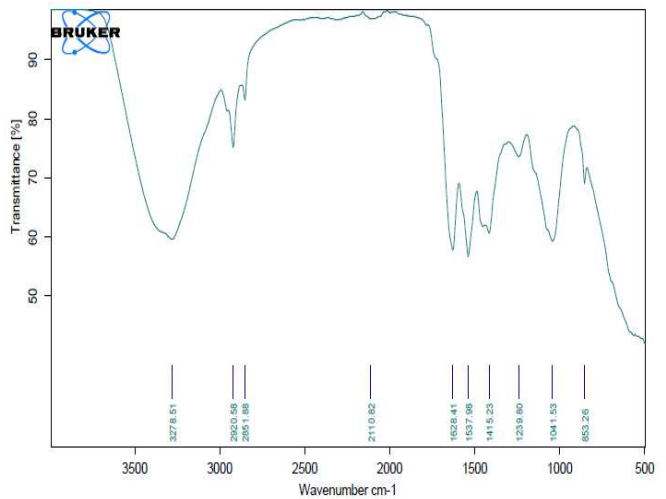

1160 
RASĀYAN J. Chem.

Vol. 14 | No. 2 |1159-1164| April - June | 2021

Table-1: The Wavenumber and Chemical Composition of Oscillatoria sp Extracts

\begin{tabular}{|c|c|c|}
\hline \multicolumn{3}{|c|}{ Methanol Extract } \\
\hline Wavenumber $\left(\mathrm{cm}^{-1}\right)$ & Functional Group & Chemical Group \\
\hline 3346 & $\mathrm{O}-\mathrm{H}$ & Hydroxyl group \\
\hline 1633 & $\mathrm{C}=\mathrm{C}$ & Alkenyl, aromatic ring stretch \\
\hline 1440 & $\mathrm{C}-\mathrm{H}$ & Alkana \\
\hline 1107 & $\mathrm{C}-\mathrm{H}$ aromatic & Alkana aromatic \\
\hline 603 & $\begin{array}{c}\text { C-O-P } \\
\text { S-S } \\
\text { C-I } \\
\end{array}$ & $\begin{array}{l}\text { Phosphate compounds } \\
\text { disulphides } \\
\text { Aliphatic iodo compounds }\end{array}$ \\
\hline \multicolumn{3}{|c|}{ Water Extract } \\
\hline Wavenumber $\mathrm{cm}^{-1}$ & Functional Group & Chemical Group \\
\hline 3278 & C-H aromatic & Alkana aromatic \\
\hline 2920 & $\mathrm{C}-\mathrm{H}$ & Methyl \\
\hline 2851 & $\mathrm{O}-\mathrm{CH}_{3}$ & Metoxy, methyl ether \\
\hline 1628 & $\mathrm{C}=\mathrm{C}$ & Alkenyl \\
\hline 1537 & $\mathrm{~N}=\mathrm{O}$ & Aliphatic nitro compounds \\
\hline 1415 & $\mathrm{~S}=\mathrm{O}$ & Organic sulphate \\
\hline 1239 & $\mathrm{P}-\mathrm{O}-\mathrm{C}$ & Organic phosphate \\
\hline 1041 & $\begin{array}{c}\mathrm{C}-\mathrm{N} \\
\mathrm{Si}-\mathrm{O}-\mathrm{Si}\end{array}$ & $\begin{array}{c}\text { Primary amine } \\
\text { Organic siloxane or silicon }\end{array}$ \\
\hline 853 & $\mathrm{C}-\mathrm{O}-\mathrm{O}-\mathrm{C}$ & Peroxides \\
\hline
\end{tabular}

Infrared spectroscopy can be used for the identification of organic and inorganic compounds. The fundamental concept of infrared activity is based on the molecule vibration or the functional group of compounds. ${ }^{20}$ The $\mathrm{C}-\mathrm{H}$ vibrations for methyl are the most characteristic of aliphatic fragment. Saturated $(\mathrm{C}=\mathrm{C}-\mathrm{H})$ and or aromatic rings were found between 3150 and $300 \mathrm{~cm}^{-1}$.

The C-H stretching was observed at about $3000 \mathrm{~cm}^{-1}$. The vibration peaks between $4000-2500 \mathrm{~cm}^{-1}$ related to $\mathrm{C}-\mathrm{H}, \mathrm{N}-\mathrm{H}$, and $\mathrm{O}-\mathrm{H}$. the peaks of $\mathrm{O}-\mathrm{H}$ are the most important in infrared spectroscopy and it was observed at 3700-3600 $\mathrm{cm}^{-1}$. The peaks for $\mathrm{N}-\mathrm{H}$ stretching were observed between 3400 and $3300 \mathrm{~cm}^{-1}$.

The microalgae contain a biological value, such as amino acids, protein, fatty acids, and antioxidants ${ }^{2}$. Based on the research, the natural antioxidant can be found in microalgae. ${ }^{21}$

\section{Antioxidant Activity}

Antioxidants are the compounds that inhibiting the initiator or propagation of oxidizing chain reaction. Natural antioxidants gave biological effects such as antibacterial, anti-inflammatory, and, antiallergic. ${ }^{22}$

(a)

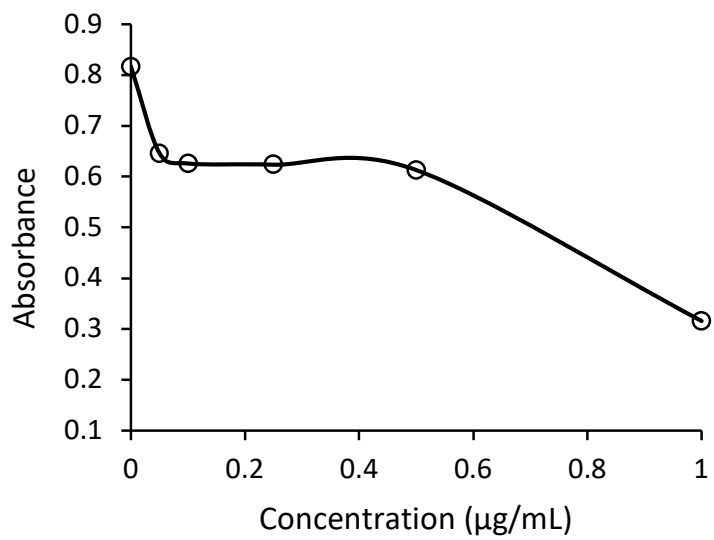

(b)

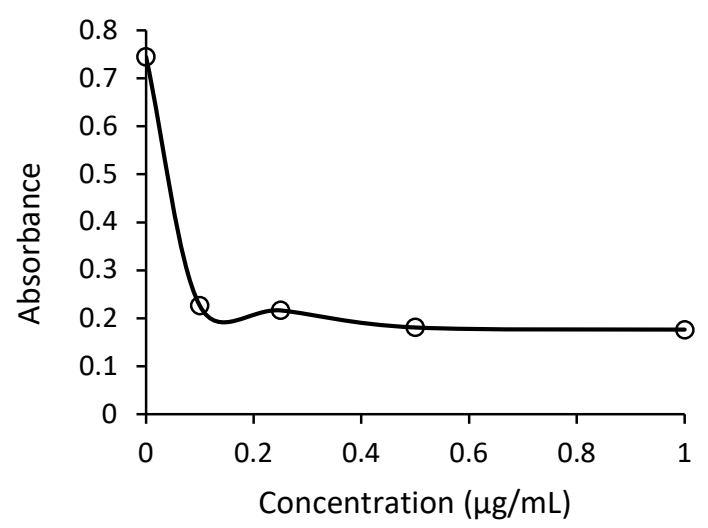

Fig.-2: The Correlation between Concentration and Absorbance (a) Methanol Extract (b) Water Extract 
RASĀYAN J. Chem.

Vol. 14 | No. 2 |1159-1164| April - June | 2021

Table-2: The Antioxidant Activity, Phenolic, and Tannin Content of Oscillatoria sp Extract

\begin{tabular}{c|c|c|c}
\hline Extract & $\mathrm{IC}_{50} \mu \mathrm{g} / \mathrm{mL}$ & Phenolic $(\mathrm{mg} / \mathrm{g})$ & Tannin $(\mathrm{mg} / \mathrm{L})$ \\
\hline Water & 0.16 & 232 & 479.23 \\
\hline Methanol & 0.85 & 201 & 319.48 \\
\hline
\end{tabular}

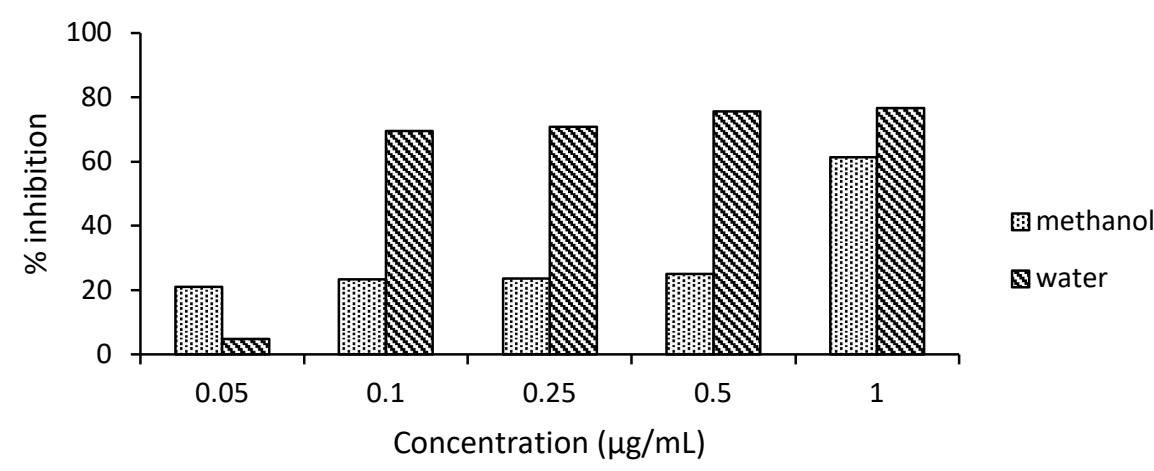

Fig.-3: The \% Inhibition of Extract in Methanol and Water

The antioxidant activity with the DDPH method showed a decrease in absorbance with the increase of inhibition. The higher of sample concentration, the higher of inhibition value. Based on Figure 2, the resulting equation for methanol extract was $\mathrm{y}=40.617 \mathrm{x}+15.447$ with $\mathrm{IC}_{50} \mathrm{was} 0.85 \mu \mathrm{g} / \mathrm{mL}$. It meaning that the sample has a strong antioxidant activity. In water extract gave an equation was $y=43.66 x+42.955$ and $\mathrm{IC}_{50}$ was $0.16 \mu \mathrm{g} / \mathrm{mL}$. Based on the experiment showed the Oscillatoria $s p$ has very strong antioxidant activity. The antioxidant activity from Oscillatoria $s p$ was strong in water extract than methanol extract.

\section{Phenolic Content}

This experiment used the method of Folin-Ciocalteu for the analysis of phenolic content. The phenolic acts as an antioxidant because of its ability to eliminate free radicals and effective in inhibiting lipid oxidation..$^{23,24}$

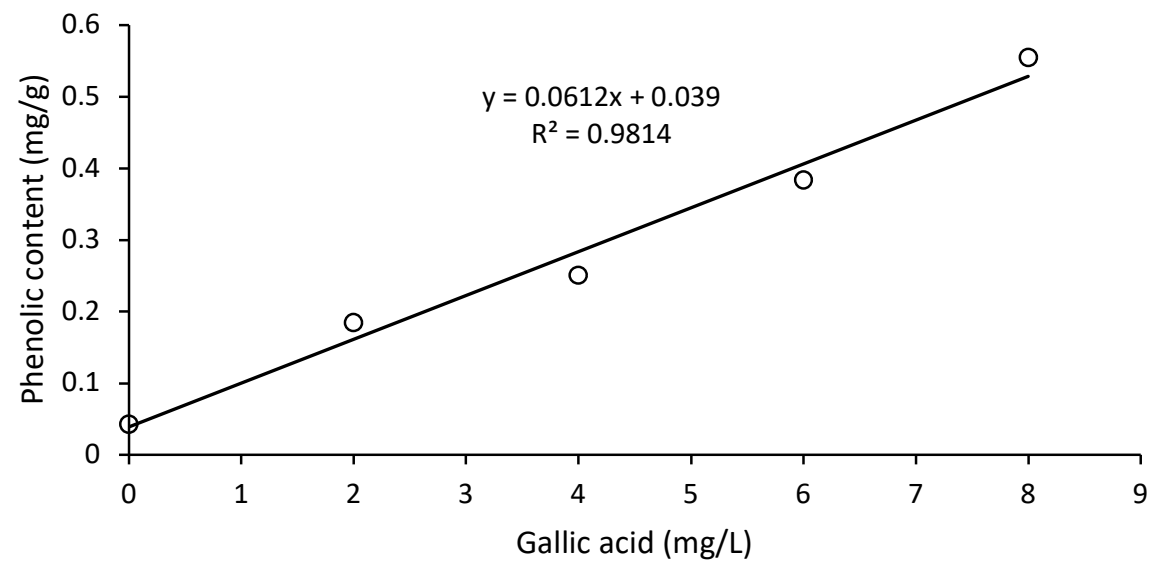

Fig.-4: Correlation between Gallic Acid and Phenolic Content

Based on this research showed that Oscillatoria $s p$ in water extract has phenolic content is higher than methanol extract. Phenolic content from water extract was $232 \mathrm{mg} \mathrm{GAE} / \mathrm{g}$ and methanol extract were 201 $\mathrm{mg} \mathrm{GAE} / \mathrm{g}$. It correlated to the antioxidant activity in water extract is higher than methanol extract. Phenolic compounds can function as antioxidants because of their ability to stabilize free radicals by giving hydrogen atoms to free radicals. ${ }^{25}$ The experiment showed an increase in phenolic content, an increase in antioxidant activity. Phenolic acid is a secondary metabolite widely distributed in the plant. Polyphenol is plant metabolites characterized by the presence of several phenol groups. ${ }^{26}$ 
RASĀYAN J. Chem.

Vol. 14 | No. 2 |1159-1164| April - June | 2021

\section{Tannin Content}

Based on the experiment resulted in the tannin content in water extract was higher than methanol extract. The water extract gave the tannin content was $479,23 \mathrm{mg} / \mathrm{mL}$ and methanol extract were $319,48 \mathrm{mg} / \mathrm{mL}$. Tannin can decrease feed intake and net metabolizable energy. Tannic acids are the polyphenol which found and shown to possess antioxidant. ${ }^{27,28}$

\section{CONCLUSION}

The Oscillatoria $s p$ in water and methanol extract has potential in antioxidant activity, phenolic content, and tannin content. The chemical structure with FTIR analysis showed the functional group in water extract has more than methanol extract. The functional group in chemical structure plays a role in antioxidant activity. The water extract has potential for functional food because they have antioxidant activity, phenolic and tannin content was more than methanol extract.

\section{ACKNOWLEDGEMENT}

Thanks for Politeknik AKA Bogor for support financial of this research.

\section{REFERENCES}

1. S. Singh, B.N. Kate, U.C. Banerjee, Critical Review Biotechnology, 25, 73(2005), DOI: $10.1080 / 07388550500248498$

2. E. Christaki, P.F. Pareri, E. Bonor, International Journal of Food Sciences and Nutrition, 62(8), 794(2011), DOI:10.3109/09637486.2011.582460

3. M. Herrero, E. Ibanez, J. Senorans, A. Cifuentes, Journal of Chromatography A, 1047, 195(2004), DOI:10.1016/j.chroma.2004.07.001

4. R. Deng, T.J. Chow, Cardiovascular Therapeutic, 28, 33(2010), DOI:10.1111/j.17555922.2010.00200.x

5. I. Priyadarshani, B. Rath, Journal of Algal Biomass Utilization , 4, 89(2012).

6. K. Goiris, K. Muylaert, I. Fraege, I. Foubert, J.D. Brabanter, L.D. Cooman, 2012, Journal of Applied Phycologr, 24, 1477(2012), DOI:10.1007/s10811-012-9804-6

7. O. Pulz, W. Gross, Applied Microbiology and Biotechnoogyl, 65, 635(2004), DOI:10.1007/s00253$004-1647-x$

8. M. Hajimahmoodi, M.A. Faramarzi, N. Mohammadi, N. Soltani, M.R. Oveisi, N.N. Varcheh, Journal of Applied Phycology, 22, 43(2010), DOI:10.1007/s10811-009-9424-y

9. S.M.M. Shanab, S.S.M. Mostafa, E.A. Shalaby, G.I. Mahmood, 2012, Asian Pacific Journal of Tropical Biomedicine, 608(2012), DOI:10.1016/S2221-1691(12)60106-3

10. M. Herrero, P.J.M. Alvarez, F.J. Senorans, A. Cifuentes, E. Ibanez, Food Chemistry, 93, 417(2005), DOI: 10.1016/j.foodchem.2004.09.037

11. L. Jaime, I.R. Meizoso, A. Cifuentes, S. Santoyo, S. Suarez, Z. Ibanez, F.J. Senorars, Food Science and Technology, 43, 105(2010), DOI:10.1016/j.lwt.2009.06.023

12. H.B. Li, K.W. Cheng, C.C Wong, K.W. Fa, F. Chen, Y. Jiang, 2007, Food Chemistry, 102, 771(2007), DOI:0.1016/j.foodchem.2006.06.022

13. A.R. Rao, R. Sarada, V. Baskara, G.A. Ravishankar, 2006, Journal of Agricultural and Food Chemistry, 54, 4593(2006), DOI:10.1021/jf060799j

14. T.T. Spitz, M. Bergman, D. Moppe, S. Grossman, S.M. Arad, Journal of Applied Phycology, 17, 215(2005), DOI:10.1007/s10811-005-0679

15. R.K. Sighn, S.P. Tiwan, A.K. Rau, T.M. Mohapatra, The Journal of Antibiotics, 1(2011), DOI: $10.1038 /$ ja.2011.21

16. K. Eguchi, H. Nagase, M. Otawa, Y.S. Endoh, K. Goto, K. Hirata, K. Miyamoto, H. Yoshimura, Chemosphere, 57, 1733(2004), DOI:10.1016/j.chemosphere.2004.07.017

17. R. Abedin, H.M. Taha, Global Journal of Biotechnology \& Biochemistry, 3(2), 22(2008).

18. A.R. Prihadi, A. Maimulyanti, B. Mellisani, Nurhasanah, Rasayan Journal of Chemistry, 13(2), 955(2020), DOI: 10.31788/RJC.2020.1325613

19. V.I. Singleton, R. Orthofer, R.M. Lamuela-Raventos, Methods of Enzymology, 299, 152(1999), DOI:10.1016/S0076-6879(99)99017-1 
RASĀYAN J. Chem.

Vol. 14 | No. 2 |1159-1164| April - June | 2021

20. Coates, Interpretation of infrared spectra, A practical Approach, Encyclopedia of Analytical Chemistry, John Wiley \& Sons, Ltd (2006), DOI:10.1002/9780470027318.a5606

21. I. Rodriguez-Gareia, J. L. G. Guil-Guerrero, Food Chemistry, 108, 1023(2008), DOI: 10.1016/j.foodchem.2007.11.059

22. O. Atalono, C.B. Adeosun, A.P. Oluyori, J. Oloto, Rasayan Journal of Chemistry, 12(3), 1052(2019), DOI: $10.31788 /$ RJC.2019.1235122

23. R. Rehman, M. Akram, N. Akhtar, Q. Jabeen, T. Saeed, S.M.A. Shah, K. Ahmed, G. Shaheen, H.M. Asif, Journal of Medicinal Plants Research, 5, 344(2011).

24. T. Okselni, A. Santoni, A. Dharma, M. Efdi, Rasayan Journal of Chemistry, 11(3), 1211(2018), DOI: 10.31788/RJC.2018.1133058

25. D.D. Sarma, S. Ghos, Rasayan Journal of Chemisty, 14(1), 19(2021), DOI:10.31788/ RJC.2021.1416098

26. S. Petti, C. Scrully, Journal of Dentisty, 37, 413(2009), DOI:10.1016/j.jdent.2009.02.003

27. I. Gulcin, Z. Huyut, M. Elmastas, H.Y. Aboul-Enein, Arabian Journal of Chemistry, 3, 43(2010), DOI: $10.1016 /$ j.arabjc.2009.12.008

28. A. Schalbert, Phytochemistry, 30(12), 3875(1991), DOI:10.1016/0031-9422(91)83426-L

[RJC-5934/2020] 